DIRECTOR AND OFFICER LIABILITY IN THE ZONE OF INSOLVENCY: A COMPARATIVE ANALYSIS

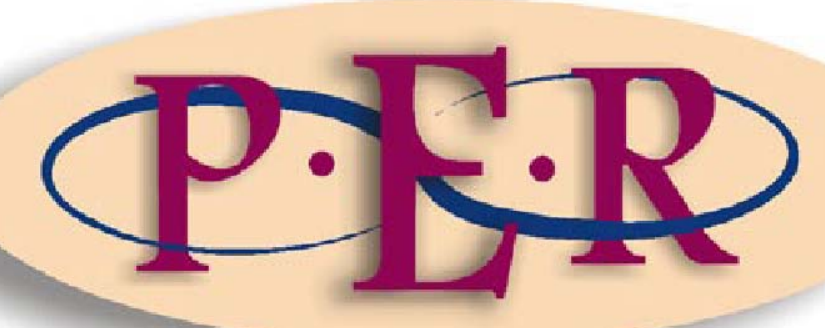

2008 VOLUME 11 NO 1 


\section{DIRECTOR AND OFFICER LIABILITY IN THE ZONE OF INSOLVENCY: A COMPARATIVE ANALYSIS}

\section{HH Rajak*}

\section{$1 \quad$ Introduction}

It is a generally accepted proposition that the duty of the directors of a company is to run the business of the company in the best interests of the company. Some, who are perhaps less pedantic about the separation in legal terms of the company from its shareholders, would extend the beneficiary of these duties to include the shareholders. Nevertheless, this separation is of crucial importance, in particular in shifting the primary liability for the debts incurred in running the business, from the individual entrepreneur, to the company which, in law, owns and carries on the business. The company is the primary debtor and the legal status of the entrepreneur is that of being a director of, and a shareholder with limited liability in, the company. Thus, in principle, the company, alone, is responsible for the debts incurred in the running of the company and the creditors are, in principle, precluded from looking to the entrepreneur for payment of any shortfall arising as a result of the company's insolvency.

It is also the case that in a number of jurisdictions statutory changes have sought, in certain circumstances, to render the directors and others who were concerned with the management of the company prior to the insolvent liquidation, liable to contribute to the assets of the company so as to assist the insolvent estate in meeting the company's debts to its creditors. This paper aims to explore this statutory jurisdiction. Before this, however, it will seek to describe briefly the process by which the shift from unlimited to limited liability trading was achieved. Thereafter, it will look at the common law response to this changed dispensation. It will end by examining briefly a comparatively new 
phenomenon, namely that of a shift in the focus of the directors' duties from company and shareholders to creditors as the company becomes insolvent and nears the stage of a formal declaration of its insolvent status. As we will discover, this new phenomenon seems to have struck a chord in many different jurisdictions, but is, on the other hand elusive and not without controversy. If, as this principle would have it, the focus of the duty of director and officers shifts to creditors when the company enters the zone of insolvency, the creditors should be able to enforce that duty before the formal declaration of insolvency. Arguably, they should also be entitled to seek information about the proposed actions of the company and they should be able to apply to court to prohibit any action which they perceive to be against their interests.

The notion of the 'zone of insolvency' may have a distinctly modern ring about it, but I hope to show that it has a long pedigree. I hope also to illustrate that it encompasses a clash between two fundamental principles in the conception and operation of limited liability companies, namely the protection of the company's creditors and the right and the duty of the directors and officers of the company to run the business of the company in the best interests of the shareholders.

Thus the first part of this paper looks forward to formal insolvency, the second looks back from formal insolvency to the actions of the directors as the company approaches its downfall. Each part is distinctive. Yet, there is an obvious link between these two parts. If the legal system does provide for the personal liability of the directors and officers who led the company into formal insolvency, this is likely to influence the conduct of those directors and officers when they perceive this to be the likely fate of the company. The threat of such personal liability may encourage decisions and conduct which further the creditors' interests and thus, informally, bring about this shift in the focus of the duty of directors and officers. 
I take the case of Salomon $v$ Salomon \& Co $L t d^{1}$ as the starting point for the exploration of these ideas. In its result, this decision greatly strengthened the position of directors and shareholders (whom I will sometimes refer to, collectively, as the entrepreneur or the entrepreneurial interest) at the expense of the creditors. Much of the post-Salomon history has been the digesting of the dispensation which was created by the decision, and the seeking to restore, or at least maintain, the balance between these competing interests.

Salomon's case was one of the great exports of the British Empire and justifiably can claim the title of father or grandfather, or maybe Godfather, of company law for colonials and colonists alike. In South Africa, where I first studied company law under the great Professor HR ('Bobby') Hahlo - later the Director of the Institute of Comparative Law at McGill University, Montreal Salomon's case had pride of place at the start of the course and was on the first substantive page of Hahlo's "Company Law Through the Cases", the first company law casebook of the English-inspired common law world.

To law students, Salomon's case meant the authority for the proposition that the company was a separate legal entity from that of the people who constituted the company, as well as the beginning of the process of wrestling with the veil of incorporation and its piercing or - in more genteel discussions its lifting. The first of these propositions is at the root of the shift in the balance of power from creditor to entrepreneur, the second is our continuing attempt to ensure that we have achieved the right balance between these two opposing commercial forces.

\section{$2 \quad$ The period leading up to Salomon}

Until the middle of the nineteenth century, the overwhelming mass of commercial trading in Great Britain was undertaken by single traders or by

1 Salomon $v$ Salomon [1897] AC 22, upholding an appeal from the court of first instance and the Court of Appeal, sub. nom. Broderip v Salomon [1895] 2 Ch 323. 
partnerships of traders, without any limit of personal liability. ${ }^{2}$ Occasional attempts to provide for limited liability by contract were either too cumbersome or were rejected by the courts. ${ }^{3}$ This was changed, or rather the process of change from unlimited to limited liability trading was started, with the passage of the Limited Liability Act in 1855. The latter act was only achieved after a spirited public debate, ${ }^{4}$ and was grafted on to the Joint Stock Companies Act of $1844,{ }^{5}$ and together these and other acts were consolidated in 1862 as Britain's first Companies Act.

When the comparison was drawn between, on the one hand, a registered company which offered limited liability to its investors and directors, and, on the other, the partners of a partnership, it is hardly surprising that there were misgivings in this new dispensation. While there could be no rational objection to seeking an escape from the labyrinthine problems which arose from the unincorporated status of the partnership compounded as they were by the much criticised procedures of the Courts of Equity, ${ }^{6}$ permitting small time entrepreneurial activity without personal liability was something else.

There was a heady mix of emotions and position in this debate. High Tories were opposed to limited liability and subscribed to the view expressed in the famous decision of Waugh v Carver ${ }^{7}$ that "he who feels the benefit should also feel the burden", itself a restatement of Chief Justice Grey's dictum some 18 years earlier "that every man who has the share of the profits of a trade, ought

2 Large infrastructural projects like the building of the railways, roads and canals and the development of the gas and electricity industries were undertaken by corporations specially created by Act of Parliament; the expense and cumbersome nature of petitioning parliament for the passage of an appropriate act was well beyond the ordinary every day merchant.

3 See eg Re Sea Fire and Life Assurance Company (Greenwood's case) (1854) 3 De GM \& G 459, 43 ER 180; Hallett v Dowdall (1852) 21 LJ QB 98.

4 The best short account of this campaign is in ch 3 of Davies and Gower Gower's Principles, but only up to and including the $6^{\text {th }}$ edition (1997). Space constraints forced the exclusion of the content of these chapters from the $7^{\text {th }}(2003)$ edition, see Davies and Gower Principles of Modern Company Law, to the regret of the current editor - see vi.

5 The first registered companies act in Great Britain, passed at a time when Gladstone was the President of the Board of Trade - the responsible Ministry.

6 See Formoy Historical Foundations of Company Law 32-36; of the many fictional accounts, it is doubtful whether anything can outdo the first page of Charles Dickens's Bleak House.

$7 \quad$ Waugh v Carver (1793) 126 ER 525, 2 Hy BI 235. 
to bear his share of the loss". 8 Support for limited liability, on the other hand, came from the radical Whigs (the predecessors of today's UK Liberals) and the utilitarian economists such as Jeremy Bentham ${ }^{9}$ and John Stuart Mill. Human nature and religion were also pressed in aid by the respective protagonists. Robert Lowe, the vice-president of the Board of Trade, who is considered largely responsible for the pioneering Limited Liability Act of 1855 , denounced the evangelical fervour of his opponents.

Unless we deal with each other upon some presumption of confidence ... the disruption of human society must necessarily follow. Fraud and wickedness are not to be presumed in individuals. $^{10}$

This evangelical opposition came from men like John Ramsay McCulloch, a prolific Scottish journalist, who was editor of both The Scotsman and the Edinburgh Review, an ardent disciple of classical Ricardo economics and a lecturer on political economy at University College London in the early 1830s. There was no separation of human nature and economics for McCulloch.

In the scheme laid down by Providence for the government of the world, there is no shifting or narrowing of responsibilities, every man being personally answerable to the utmost extent for all his actions. But the advocates of limited liability proclaim in their superior wisdom that the scheme of Providence may be advantageously modified, and that debts and contracts may be contracted which the debtors though they have the means, shall not be bound to discharge. ${ }^{11}$

One of McCullough's best known pupils was Lord Overstone, a top flight political economist of the day who described the Limited Liability Act as a fraud on creditors, a harbinger of -

reckless speculation. ... A great disease ... was likely to settle upon this country - the indiscriminate desire for limited liability.

$8 \quad$ Grace $v$ Smith (1775) 96 ER 587, 588; 2 Wm BI 997.

9 "Were it lawful for everyone to engage in commercial undertakings for a limited amount, how many facilities would be afforded to men of genius! All classes of society would furnish assistance to inventive industry" Bentham Manual of Political Economy.

10 Lowe in the British House of Commons, 1 February 1856.

11 McCulloch Considerations on Partnership with Limited Liability 10-11. 
Parliament had to act, in his view, to stem the rising tide of over-trading and speculation by making -

the laws of bankruptcy more stringent, and the responsibility of all traders more severe. ${ }^{12}$

Yet, despite its obvious appeal, limited liability was slow in actually coming. For one reason or another, the established pattern of high par value shares remained the order of the day, ${ }^{13}$ and there was also a strong body of opinion which held that the protection of limited liability was intended only for investors in large enterprises and was not for single traders or small partnerships. This controversy was settled by Salomon's case. Salomon had registered a company (A Salomon and Co Ltd), of which he was the overwhelming shareholder and managing director. Thereafter he had sold the business he ran as an individual trader, to that company for -

a sum which represented the sanguine expectations of a fond owner rather than anything that can be called a businesslike or reasonable estimate of value. ${ }^{14}$

Within eighteen months, the business failed and the company went into insolvent liquidation. The liquidator claimed that Salomon was obliged to indemnify all the creditors of the company.

The liquidator's claim succeeded in the court of first instance and this decision was upheld by the Court of Appeal, but a unanimous House of Lords overturned the decision of the Court of Appeal. The express legal basis for the decisions of the court of first instance and the Court of Appeal was that the company was merely Salomon's agent or trustee and that Salomon as the principal or the beneficiary, was liable for the acts and debts of his agent or trustee. Lord Justice Lindley - one of the greatest of all company law judges in

12 British House of Lords debates, 22 May 1855.

13 It is not uncommon to find share par values at $£ 100$ or higher during the last half of the nineteenth century.

14 Lord Macnaghten, Salomon v Salomon [1897] AC at 49. 
England - sat in the Court of Appeal and in his judgment summarised the liquidator's case in the following terms: ${ }^{15}$

The appeal raises a question of very great importance, not only to the persons immediately affected by the decision, but also to a large number of persons who form what are called 'one-man companies.' Such companies were unheard of until a comparatively recent period, but have become very common of late years.

There can be no doubt that in this case an attempt has been made to use the machinery of the Companies Act, for a purpose for which it was never intended. The legislature contemplated the encouragement of trade by enabling a comparatively small number of persons- namely not less than seven ${ }^{16}$ - to carry on business with a limited joint stock or capital, and without the risk of liability beyond the loss of such joint stock or capital. But the legislature never contemplated an extension of limited liability to sole traders or to a fewer number than seven. ... Although in the present case, there were, and are, seven members, yet it was manifest that six of them are members simply in order to enable the seventh himself to carry on business with limited liability.

... The company in this case has been regarded by [the judge in the court below] as the agent of Aron Salomon. I should rather liken the company to a trustee for him - a trustee improperly brought into existence by him to enable him to do what the statute prohibits.

Another of the judges in the Court of Appeal was less measured in his language: ${ }^{17}$

It would be lamentable if a scheme like this could not be defeated. If we were to permit it to succeed we would be authorizing a perversion of the Joint Stock Companies Act. We should be giving vitality to that which is a myth and a fiction. ... To legalize such a transaction would be a scandal.

But legalise this 'scandal', the House of Lords did. In effect, the basis for the various concurring speeches in the House of Lords was that Salomon had done no more and no less than was required of him to create a limited liability

15 Broderip v Salomon [1895] 2 Ch at 336, 337, 338.

16 As it happened, Salomon's wife and five children made up the then minimum of 7 for a registered company.

17 Broderip v Salomon [1895] 2 Ch at 340-341. 
company. The rest followed. With the company created, a separate legal person came into existence and conducted its own business, entered into its own contracts (including a contract to purchase the business from Salomon) and there was nothing in the statute to suggest that this was wrongful. Lord Herschell, expressed this view in the following terms: ${ }^{18}$

It may be that a company constituted like that under consideration was not in the contemplation of the legislature at the time when the Act authorizing limited liability was passed; that if what is possible under the enactments as they stand had been foreseen a minimum sum would have been fixed as the least denomination of share permissible; and that it would have been made a condition that each of the seven persons should have a substantial interest in the company. But we have to interpret the law, not to make it; and it must be remembered that no one need trust a limited liability company unless he so please, and that before he does so, he can ascertain, if he so please, what is the capital of the company and how it is held.

This was a most significant moment in the history of British corporate and commercial law and it shaped much that was to come, in particular that the financial burden of corporate failure would be thrown on to the creditors. Investors and more importantly directors, executives and management would be relieved of the threat of losing their own wealth as a consequence of business failure. The decision of the House of Lords - sanctioned as it must be taken to have been by the legislature in not altering the Companies Act in the wake of this decision - could be seen as an open invitation to the entrepreneur, small, as well as big, to go out and trade for all that his or her creditors were worth. The issue was not so much limited liability for the passive investor - few if any begrudged the latter's protection, indeed this was necessary to secure continued investment. ${ }^{19}$ But limited liability for those who managed and directed the company, that is, those in a position to make mistakes, to conduct their businesses without proper care and attention, and worse, to abuse the faith invested in them and to be guilty of fraud, was something else.

19 The UK's Limited Partnership Act 1907 provided similar protection for the passive investor in a partnership, but by then the popularity of the registered company made this limited liability partnership all but unnecessary. 
Under the ancien regime, a trader was liable to the full extent of his fortune for debts incurred in the carrying on of his business. Creditors had to be paid in full, as far as this was possible with no artificial limits protecting part or all of the debtor's assets. The new regime not only removed that unlimited liability; it also created the machinery for the replacement of the human trader by the company trader. The latter remained fully liable without limit, just as its predecessor had been. Furthermore as a separate person, it, alone entered into the trading contracts and incurred the debts, it alone owned the property with which and on which the business was conducted, and where litigation was necessary, it, the company, was recognised as the appropriate litigant. Arguably, the limited liability conferred on the investors in the company was unnecessary and served only to make the investor feel more secure. ${ }^{20}$ Yet, for all the seamless sophistication by which the new order replaced the old, the potential for fundamental change was obvious and was clearly recognised by the four judges below in Salomon's case.

The four judges could not and did not resist the plain language of the Companies Act of 1862, under which a company when created was a separate person from those who had created it. Indeed their resort to established principles to render Aron Salomon liable for the debts of A Salomon \& Co - that a principal was responsible for the acts of his agent and a beneficiary had to indemnify his trustee for debts incurred in the execution of the trust - rested on the separate personalities of Salomon and the company. For them, the alternative was of such a revolutionary nature, that it could not have been intended by parliament. Limited liability had to remain restricted to investors in large corporations. ${ }^{21}$ But the House of Lords famously thought otherwise. There

20 See the very interesting discussion - and sources quoted - by Staughton $\mathrm{j}$ in $\mathrm{JH}$ Rayner Mincing Lane $v$ Department of Trade and Industry [1987] BCC 430-431.

21 This view has had more than its fair share of adherents, right up to the present. Even hardened proponents for limited liability like Easterbrook and Fischel Economic Structure of Corporate Law 50-54, accept that limited liability has less justification in small companies than it does in larger ones. See also Cohen 1998 Oklahoma Law Review 438ff; Vandervoort 2004 DePaul Bus \& Comm LJ 53-56. 
was no room for inferring such an intention and thus, they helped propel Britain into a new age.

\section{Directors duties and the zone of insolvency - the early period}

Salomon's case made more urgent the need for some vigilance on the part of creditors as to the solvency of their debtors who were registered companies. They had, after all, been told so by the House of Lords that "[e]very creditor is entitled to get and to hold the best security the law allows him to take". ${ }^{22}$ And, as we shall see shortly, those who could - essentially lenders as opposed to trade creditors ${ }^{23}$ - did. But as for those who could not, well, it was a brave new world and at least they knew the scoRe

The unsecured creditors of A Salomon and Company Limited, may be entitled to sympathy, but they have only themselves to blame for their misfortunes. They trusted the company, I suppose, because they had long dealt with Mr Salomon, and he had always paid his way; but they had full notice that they were no longer dealing with an individual and they must be taken to have been cognisant of the memorandum and of the articles of association ${ }^{24}$

Having notice was all very well, but the only real protection for most traders was to abstain from dealing with a limited liability company, hardly an option for most. Investigating and monitoring the solvency of the company was equally illusory. But some lenders, on the other hand, could and did take full advantage of two significant instruments of credit and security - the floating charge and receivership. The latter was of ancient vintage as a means of managing leased real property, but emerged in the late nineteenth century as a vital adjunct to the floating charge, which itself dated from about $1870 .^{25}$

22 Lord Macnaghten in Salomon v Salomon [1897] AC at 52.

23 This distinction was recognised in relation to partnership creditors in an early example of creditor prioritisation, by the enactment of the Partnership (Amendment) Act 1854 (known as Bovill's Act after its mover in the House of Lords, Lord Chief Justice Bovill) subsequently codified as s 2 and 3 in the Partnership Act 1890.

24 Lord Macnaghten in Salomon v Salomon [1897] AC at 52-53; see also Lord Herschell, quoted above, and text associated with supra $\mathrm{n} 18$.

25 It is first mentioned in Re Panama, New Zealand and Australian Royal Mail Company (1870) 5 Ch app 818; see Pennington 1960 Mod LR 630, and n 1 for other examples in the $40 / 211$ 
Salomon, himself, had loaned money to the company and had secured his loan by means of a floating charge. The only one of the nine judgments in all courts to make this clear is that of Lord Justice Kay. ${ }^{26}$ Others speak only of the debenture issued to Salomon so it can be safely assumed that at that stage, anyway, a debenture was taken to include a floating charge. ${ }^{27}$ Indeed, it was this aspect of the Salomon case which, commercially speaking, was the most crucial. Not only was Salomon not obliged to indemnify the company's creditors, but the floating charge enabled him to be first in the queue of creditors. This must have added insult to the injury evinced by the four judges below and there is a somewhat lame recognition of this in the House of Lords:

For such a catastrophe as has occurred in this case some would blame the law that allows the creation of a floating charge. But a floating charge is too convenient a form of security to be lightly abolished. I have long thought, and I believe some of your Lordships also think, that the ordinary trade creditors of a trading company ought to have a preferential claim on the assets in liquidation in respect of debts incurred within a certain limited time before the winding-up. But that is not the law at present. Everybody knows that when there is a winding-up debenture-holders generally step in and sweep off everything; and a great scandal it is. ${ }^{28}$

Receivership had been a means by which a landlord recovered possession of the leased property, and was now evolving, alongside the floating charge to meet the needs of commercial lenders, to enable the latter to manage the business over whose assets the charge conferred security for the loan. ${ }^{29}$ This provided the opportunity for a debenture-holder who feared for the solvency of the debtor, to seek to enforce the security right up to the point of appointing a manager of the business. The early cases are concerned with a debtor on the

1870 s.

26 Broderip $v$ Salomon [1895] 2 Ch at 343 (the headnote also makes this clear).

27 Without this, of course, 'debenture' would be little more than a fancy term for an unsecured loan.

28 Lord Macnaghten, Salomon v Salomon [1897] AC at 53.

29 See eg Peek v Trinsmaran Iron Company 2 Ch D 115; Makins v Percy Ibotson \& Sons [1891] 1 Ch 133; Edwards v Standard Rolling Stock Syndicate [1893] 1 Ch 574; In Re Victoria Steamboats, Limited [1897] 1 Ch 158. 
brink of insolvent liquidation, when, to use the modern idiom, the debtor would quite clearly have entered within the zone of insolvency.

Given that the appointment of a receiver was then in the discretion of the court, ${ }^{30}$ the issue remained open as to under what circumstances during the life of the debtor, the court would accede to an application such an appointment. On the one hand, the creditor would undoubtedly be looking for protection of the assets which secured the loan; on the other hand the debtor was not in liquidation. In Re New York Taxicab Company Limited, ${ }^{31}$ it was made clear that mere insolvency on the part of the debtor was not sufficient to sustain such an application. Although the debtor's assets were insufficient to secure the loan in full, and, if realised, would be insufficient to repay the principal and interest arrears owing to the debenture-holders, this did not justify the appointment of a receiver. The assets were not in jeopardy in the sense that there were no proceedings for their seizure; nor were any winding-up proceedings threatened. $^{32}$

The balance between, on the one hand, an insolvent debtor wishing to continue to run its business and, on the other, secured creditors fearful that this would further deplete the security, proved even in these early post-Salomon days to be elusive. A few months after the New York Taxicab application, the matter was back in court in Re Tilt Cove Copper Company Limited. ${ }^{33}$ On this occasion, again there was no threat of seizure of the debtor's assets, nor of the initiation of liquidation proceedings. The debenture was not enforceable and the debtor had a reserve fund made up of accumulated profits of some $£ 10,000$. The company was proposing to distribute the fund among the shareholders as share dividends. Yet here the court distinguished the New York Taxicab case and granted the debenture-holder's application for the appointment of a

30 This was later refined so as to make this a matter of contract between creditor and debtor.

31 Re New York Taxicab Company Limited [1913] 1 Ch 1.

32 As they had been in the appointment of the receiver in Victoria Steamboat decision [1897] 1 Ch 158.

33 Re Tilt Cove Copper Company Limited [1913] 2 Ch 588. 
receiver. The crucial difference was that there, although the company was insolvent -

\begin{abstract}
there was nothing to show that, if the company continued to carry on its business as it was then doing, it might not before long again be prosperous and in a position to pay all its debenture-holders as well as its other creditors. It was not a case where the business of the company had come to an end... ${ }^{34}$
\end{abstract}

In the Tilt Cove case, on the other hand, the company's business was clearly finished. It had long mined a copper mine - which, incidentally was situated on the coast of Newfoundland - and there was powerful evidence that all the copper had been exhausted. Once the reserve fund went there would be hardly assets left in the company and clearly though there were no arrears in interest payments, there would be insufficient to repay the principal loan. This justified a finding that the assets being in jeopardy and, therefore, the appointment of a receiver.

Credible evidence as to the cessation of the business (and the settled decision to assume no other business - which it might be said is implied in the Tilt Cove case) is critical. In a case where all that is wanting for an insolvent liquidation is the formal order - which we are led to believe was the case in Tilt Cove - it would seem eminently arguable that the debtor has entered the zone of insolvency and that the beneficiaries of the directors' duty have been switched from shareholders to creditors. Yet a question remains - which creditors? Secured creditors and unsecured creditors may well have different interests, especially if the unsecured creditors have a plan for the resuscitation of the debtor's business. The issue might then be the credibility of such a plan as against the superior status of the secured creditors. We will explore the essentially modern phenomenon of the shift of duty in the zone of insolvency, shortly, but before doing so we need to refer to a further complication in the post-Salomon period, the decision in Lawrence $v$ West Somerset Mineral Railway Company. ${ }^{35}$ 


\section{$4 \quad$ Lawrence's case}

The facts of Lawrence's case differ little from that of Tilt Cove. The defendant company's only asset - $£ 5,500.00$ annually from the lease of a railway which it owned - was about to expire. The lease was about to run out, the railway no longer carried traffic and the line had been scrapped. On receipt of the (final) annual rent, the company proposed to distribute this in accordance with the usual pattern - in interest payments to the debenture stockholders and dividends to the preference and ordinary shareholders. The proceedings were brought by the debenture-holders for an injunction to prohibit the distribution on the grounds that the following year there would be no or no sufficient assets to repay the principal loan. There were no arrears in interest payments, nor any other breaches of covenant, and, therefore nothing on which to base a case for the enforcement of the charge.

The evidence of the end of the company's business seemed as cogent as the corresponding evidence in Tilt Cove (The railway was said to be "practically derelict and [could] never be reopened and worked at a profit"). The only difference was in the nature of the claim. Whereas in Tilt Cove the proceedings had been for the appointment of a receiver on the grounds that the debtor's assets were in jeopardy, here the proceedings were based on the claim that the money received should be treated as capital, rather than profits and therefore could not be used for a dividend distribution (which according to longstanding principles could only be paid out of profits and never out of capital). One of the submissions on behalf of the debenture-holders was formulated in 'zone of insolvency terms',

...the directors of the company are quasi-trustees, and it is their duty as business men to set aside part of the funds coming to them for depreciation and loss of capital. ${ }^{36}$ 
The court rejected the claim. The "only matter" according to the judge was "the true character of the fund in dispute" and the $£ 5,500.00$ was profit and according to the principle then prevailing, there was no obligation to make good any previous years' losses before declaring dividends. The clear thrust of this decision was underlined by the further ruling that the debenture-holders, in fact, had no locus standi to bring the claim.

That there may be circumstances in which the Court would interfere at the suit of a debenture stock holder in the plaintiff's position to restrain the company from doing acts to his injury I do not doubt, but where the sole relief claimed is a declaration that a particular application of moneys in which the stockholder has no direct or immediate interest, and upon which he has no specific charge, will be ultra vires the company, I do not think I ought to hold the plaintiff competent to maintain the action. ${ }^{37}$

Lawrence's case emphasised the principle of entrepreneurial control. It followed the spirit of Salomon and resisted the route opened up by the receivership appointment cases where the debtor's assets were held to be in jeopardy. Yet, as far as UK entrepreneurialism was concerned, it was something of a pyrrhic victory for the entrepreneur. Loan creditors abandoned the court-based route of receivership appointments to seize control of the debtor's business and concentrated instead on expanding the contractual route offered by the floating charge. It was not long before provisions in the charge were upheld, allowing the creditor to appoint a receiver out of court, not only to protect the assets, but also to manage the business to the exclusion of the debtor's directors, and almost entirely in the interests of the secured creditor. ${ }^{38}$

In many ways, the comprehensive control over the debtor which the receiver, appointed by the debenture-holder, came to exercise rendered unnecessary any thought in UK commercial practice, of the concept of the zone of insolvency and the shift of focus from shareholders to creditors. Once a debtor, which had

37 At 257.

38 Preferential creditors had to be paid before any reduction could be made in the secured creditor's debt, as was discovered to the embarrassment of at least two out of court appointed receivers, see Westminster Corporation v Haste [1950] Ch 442 and Inland Revenue Commissioners $v$ Goldberg [1972] Ch 498. The current statutory provision is S 40(2), UK Insolvency Act 1986. 
granted a floating charge to a lender to secure an overdraft for the running of the business, went above the permitted overdraft limit, the lending bank could consider using its trump card of appointing an out of court receiver, regardless of whether a theoretical notion of an objectively assessed 'zone of insolvency' had been entered. In fact, the reign of the receiver in the UK came to an end on September 15, 2003, when the Enterprise Act of 2002 drastically curtailed the right of the debenture-holder to appoint a receiver. ${ }^{39}$ This was part of a package designed to strengthen the business rescue culture and it included measures to expand the scope of the court-based business rescue regime, Administration, which had, since its creation by the Insolvency Act 1986, lived its life in the shadow of receivership.

\section{The liability of directors and officers to the insolvent estate}

\subsection{The common law response to Salomon}

For the UK, Salomon's case created or confirmed a decided shift in the balance between entrepreneur and creditor. Limited liability trading was soon afterwards established in Australia, Canada, South Africa and New Zealand. Similar economic orders were also being set in place throughout the nineteenth century on the United States, ${ }^{40}$ and many European countries and their empires. And with the new order, went the need to ensure that entrepreneurs did not abuse limited liability trading. At first, the courts assumed this guardianship with the limited tools that were available under the common law, where that was the prevailing legal system.

The outlawing of fraud was always an imperative and this helped to create a doctrine which became and remains widespread, namely the lifting or piercing of the veil of incorporation, enabling the court to look to the individual

40 See Alexander 1992 Harv L Rev 415. ("... unlimited shareholder liability was the general American rule until the early nineteenth century. [But b]y 1850, most states had enacted statutes providing for limited liability," though some states retained provisions for "double shareholder liability," and, "in California, pro rata shareholder liability survived until 1931.") 
entrepreneur and to strip from him or her, the protective covering of the limited liability company. The judgments of the court of first instance and of the court of appeal in Salomon's case itself may be regarded as very early instances of this doctrine. An early post-Salomon example appeared in the UK in the decision in Re Darby, ${ }^{41}$ in which the court stripped the corporate protection from two fraudsters who had attempted shield from the public being invited to subscribe for shares in a company being promoted, the fact that that were both undischarged bankrupts.

The doctrine of lifting the veil of incorporation has spawned a huge jurisprudence Aside from commercial abuse, other issues have demanded that courts and legislatures eliminate the use of the corporate form for the avoidance of legitimate obligations. In the matter of debt avoidance, while the courts were well able to cope with fraudulent conduct on the part of debtors, anything less than fraud posed a serious systemic problem. The grant of limited liability to entrepreneurs was designed to encourage the taking of risks, so to punish commercial conduct that did not amount to fraud by stripping away the protection of limited liability, might run counter to the commercial order which had been established.

Legal systems frown on negligence, just like they do on fraud, but the line between legitimate risk-taking and negligent conduct may be very difficult to draw. Courts, with their usual and well-justified concern to avoid the use of hindsight, coupled with their often professed reluctance to get involved in the substance of business decision-making, have generally avoided this troubling area. Courts in the United States have tended to tread less warily than the courts in the United Kingdom, and one interesting line of authority in the U.S. which may constitute an exception to this abstinence, has been the development of the principle of piercing the veil of incorporation where the company has been under-capitilised. ${ }^{42}$

41 Re Darby [1911] 1 KB 95.

42 See eg Ballantine Corporations 303; Berle 1947 Colum L Rev 349-353; Hamilton 1971 Texas LR 985-989; Campbell 1975 Ky LJ 23; but see Thompson 1991 Cornell L Rev 1065. 


\subsection{The legislative response to Salomon}

Some jurisdictions, specifically the UK, Australia and South Africa have enacted specific legislation which empowers a liquidator - and in South Africa others as well ${ }^{43}$ - to look to errant directors and officers to contribute to the insolvent estate where their errancy has contributed to the insolvent liquidation. ${ }^{44}$ Other jurisdictions, most notably the United States and Canada still rely largely on the common law, although, the so-called 'oppression remedy' a creature of the Canadian Business Corporations Act, is thought broad enough to encompass the complaints of creditors, where directors of a corporation have used their powers -

in a manner that is oppressive or unfairly prejudicial to or that unfairly disregards the interests of any security holder, creditor, director or officer. $^{45}$

This rather wide-ranging provision looks better suited to intra-corporate disputes, within solvent companies, but its terms of access to "any other person who, in the discretion of a court, is a proper person to make an application under this [provision]," 46 applies to ordinary creditors only at the court's discretion.

English law has long had provision to enable a liquidator to seek a contribution to the company's insolvent estate from directors whose actions prior to the insolvent liquidation have amounted to what is called fraudulent trading. This was first introduced in $1929,{ }^{47}$ and is now in the Insolvency Act $1986 .{ }^{48}$ It has to be said, however, that this provision has proved to be unsatisfactory, almost from its very inception. It was held to apply only with the soundest of proof of fraud and it left unanswered the issue of whether such provision should be

43 See the discussion below of s 424, South African Companies Act 61 of 1973.

44 See s 213-215, UK Insolvency Act 1986, s 588G, Australian Corporations Act 2001.

$45 \mathrm{~S} 241(2)(\mathrm{c})$.

46 S 238(d).

47 As s 275 of the Companies Act 1929.

$48 \mathrm{~S} 213$. 
available where the directors' conduct was less than fraud but also not innocent. This, in itself, was a reason to seek an alternative basis on which to hold directors liable, where their management caused or contributed to the failure of their companies.

In 1962, the Jenkins Committee drew attention to the -

widespread criticism that the Companies Act as a whole does not at present deal adequately with the situation arising from fraud and incompetence on the part of directors - particularly directors of insolvent companies. ${ }^{49}$

That committee went on to recommend a somewhat cautious extension of the law, namely that -

directors and others, who have carried on the business of the company in a reckless manner [should be] personally responsible without limitation of liability, for all or any of the debts or liabilities of the company if the court so declares on the application of the official receiver or the liquidator or any creditor or contributory of the company. ${ }^{50}$

This recommendation was not acted upon and the issue was further discussed by the Cork Committee, ${ }^{51}$ which commented as follows in its report: ${ }^{52}$

The opportunity to implement these or any analogous proposals has never been taken, with the result that there is now universal dissatisfaction and frustration with this branch of the law. This is to be particularly deplored because it breeds both disrespect and contempt for the law in a context where there is need to enlist public support in an endeavour to promote the highest standards of business probity and competence.

A further mischief identified by the Cork Committee was the ease with which the directors and other officers of failed companies might continue their unsavoury and sometimes corrupt practices by trading through newly created companies and other business organisations. Indeed, in the most grotesque of

49 Report of the Company Law Committee at par 497.

50 Ibid par 503(b).

51 Report of the Review Committee on Insolvency Law and Practice ('Cork Report').

52 Ibid par 1738. 
such cases, the few remaining assets of the failed company could be sold off at 'knockdown' prices to the newly created companies leaving creditors unpaid and corrupt directors not merely unpunished for their incompetence, but even benefiting thereby. ${ }^{53}$

The then-existing machinery - proceedings to hold directors and other officers personally liable for the debts of the company - depended upon showing that they had carried on the business with the intent to defraud creditors. The courts interpreted this akin to criminal fraud, thereby making it particularly difficult to establish liability under this provision, bearing in mind the absence of any remedy for what is the much more common case, namely negligence or incompetence on the part of the directors. The equating of the criminal act of fraud with civil liability led to the virtual absence of any remedy for innocent unsecured creditors, despite acts of gross incompetence on the part of the directors.

In the event, the Cork Committee recommended what was broadly a doublefronted attack on these various mischiefs:

'It is right', the Committee urged, ${ }^{54}$ 'that it should be an offence to carry on a business dishonestly; and right, that, in the absence of dishonesty, no offence should be committed. Where, however, what is in question is not the punishment of an offender, but the provision of a civil remedy for those who have suffered financial loss, a requirement that dishonesty be proved is inappropriate. Compensation ought ... to be available to those who suffer foreseeable loss as a result, not only of fraudulent, but also of unreasonable behaviour'.

The purpose of this recommendation was to substitute an objective test to determine the directors' personal liability for the subjective one which existed. The essence of the Committee's proposals was summed up by its recommendation that - 
if the directors at any time consider the company to be insolvent, they should have a duty to take immediate steps for the company to be placed in receivership, administration or liquidation. Failure to do so would normally expose any director who is party to the company's continued trading to civil liability. ${ }^{55}$

This recommendation was enacted by section 214 of the Insolvency Act 1986, which provides:

(1) Subject to subsection (3) below, if in the course of the winding-up of a company it appears that subsection (2) of this section applies in relation to a person who is or has been a director of the company, the court, on the application of the liquidator, may declare that that person is to be liable to make such contribution (if any) to the company's assets as the court thinks proper.

(2) This subsection applies in relation to a person if -

(a) the company has gone into insolvent liquidation,

(b) at some time before the commencement of the windingup of the company, that person knew or ought to have concluded that there was no reasonable prospect that the company would avoid going into insolvent liquidation, and

(c) that person was a director of the company at that time;

(3) The court shall not make a declaration under this section with respect to any person if it is satisfied that after the condition specified in subsection (2)(b) was first satisfied in relation to him that person took every step with a view to minimizing the potential loss to the company's creditors as (assuming him to have known that there was no reasonable prospect that the company would avoid going into insolvent liquidation) he ought to have taken.

(4) For the purposes of subsections (2) and (3) the facts which a director of a company ought to know or ascertain, the conclusions which he ought to reach and the steps which he ought to take are those which would be known or ascertained or reached or taken, by a reasonably diligent person having both - 
(a) the general knowledge, skill and experience that may reasonably be expected of a person carrying out the same functions that are carried out by that director in relation to the company, and

(b) the general knowledge, skill and experience that that director has.

(5) The reference in subsection (4) to the functions carried out in relation to a company by a director of the company includes any functions which he does not carry out but which have been entrusted to him

(6) For the purposes of this section, a company goes into insolvent liquidation if it goes into liquidation at a time when its assets are insufficient for the payment of its debts, and other liabilities and the expenses of winding-up.

(7) In this section 'director' includes a shadow director.

The Australian equivalent to the concept of the British wrongful trading provision is 'insolvent trading', ${ }^{56}$ and which, like section 214 of the UK Insolvency Act, moves away from the earlier and now quite outmoded concept of fraudulent trading. The Australian provision has a more directed focus than the British provision in that there is a positive duty placed on the director to ensure that no further debts are incurred when the company is insolvent or would become insolvent as a result of the debt. There must be reasonable ground for suspecting that the company was insolvent or would become insolvent at the time of the incurring of the debt. The suspicion must involve "a positive feeling of actual fear or misgiving amounting to an opinion which is not supported by sufficient evidence", 57 that is to say a lower threshold than expecting or knowing that the company is insolvent. The standard for suspecting the insolvency is that of the awareness of insolvency by a reasonable person in a like position in a company in the company's circumstances. Like the British provision, the Australian provision applies only to directors, but the definition is wide enough to include shadow or de facto directors. 
The South African provision has a similar object to the British and Australian provisions, but has some novel features. It provides as follows:

If it at any time appears that any business of a corporation was or is being carried on recklessly, with gross negligence or with intent to defraud any person or for any fraudulent purpose, a court may on the application of the Master, or any creditor, member or liquidator of the corporation, declare that any person who was knowingly a party to the carrying on of the business in any such manner, shall be personally liable for all or any of such debts or other liabilities of the corporation as the court may direct, and the court may give such further orders as it considers proper for the purpose of giving effect to the declaration and enforcing that liability.

It is not limited in its application to directors, nor to the circumstances of the company being insolvent, although the latter is probably of little significance because if the company is solvent, the creditor's debt will be paid in the normal way. But the fact that it is not so limited is underlined by the fact that its use is not limited to a liquidator, but is also available, inter alios, to creditors and members of the company. The possibility has been explored of the use of this provision - in fact of the equivalent section to the same effect in the South African Close Corporations $A c t,{ }^{58}$ - as a fast track debt-enforcement process, where the company is not insolvent. This was successful in one instance, ${ }^{59}$ but this was clearly contradicted by a later case of the South African Court of Appeal. ${ }^{60}$ The later court held that the provision should not be available where the company was able to meet the debt. Thus even if the person who acted on behalf of the company had been reckless or even fraudulent, this should be of no concern to the creditor, whose only interest is the recovery of the debt. This would, with respect, seem to be the preferable approach to a provision whose purpose, arguably, is the protection of creditors rather than the punishment of errant management. ${ }^{61}$ Apart from this it would seem unnecessary to import into the debtor/creditor relationship alien concepts such as to the state of the debtor's mind, unless the circumstances were commercially compelling.

58 S 64 (1), Close Corporations Act 69 of 1984.

59 Harri v On-Line Management 2001 (4) SA 1097.

60 L \& P Plant Hire v Bosch 2002 (2) SA 662.

61 See Sigwadi 2003 SA Mercantile LJ 303. 
Such compelling commercial circumstances might be said to arise where the principle of protecting creditors intersects with the principle of encouraging the rescue of potentially viable insolvent businesses. This has been considered by the South African courts in relation to the intersection between section 424 of the Companies Act and the provision which enables a scheme or arrangement to be made between an insolvent company and its creditors, so as to seek the rescue of that company. The provision in the South African Companies Act, ${ }^{62}$ closely resembles that of other jurisdictions, ${ }^{63}$ and encourages the rescues of businesses where this seems attainable as opposed to what might otherwise be a wasteful liquidation. The precise question that arose was the status of a pre-existing debt after a scheme or arrangement had been agreed. Did this debt remain in existence after the scheme was agreed, more particularly did the erstwhile creditor remain a creditor within the meaning of this term under section 424 , so as to be qualified to present an application based on the alleged reckless trading of a director of the company debtor? This question was answered in the affirmative. ${ }^{64}$

It is interesting to reflect on the distinction between this holding and that which rejected the use of section 424 when the company debtor was not insolvent. In both instances, the company was not in liquidation and was continuing to trade. Yet, in the latter instance, the company was no longer under any obligation to pay the debt in view of the agreed scheme of arrangement under section 311 of the South African Companies Act. The interpretation of the court, that the erstwhile creditor remained a creditor for the purposes of section 424 , is in line with the protection of creditors being the primary purpose of the section. ${ }^{65}$

The experience of these countries where there is specific legislation aimed at providing creditors with a claim against errant directors and other officers where the debt is irrecoverable from the company, is mixed. The imperative remains

62 S 311.

63 See eg, s 428, UK Companies Act 1985, and s 895ff, Companies Act 2006.

64 See Pressma Services v Schuttler 1990 (2) SA 411; Lordon v Dusky Dawn Investments 1998 (4) SA 519.

65 See Sigwadi supra n 61 at 387. 
not to disturb the delicate balance between encouraging entrepreneurial initiative and protecting creditors against far-fetched, outlandish and fraudulent conduct on the part of the entrepreneur. The more carefully manicured the terms of the legislation to take account of this imperative, the more it is subject to interpretation. Given the court's concern to avoid hindsight and to second guess business decisions, there is little room for manoeuvre. Added to this, there are issues such as the cost of the proceedings - especially in the circumstances of an insolvent estate - and the possibility that even in successful applications, the errant directors and officers may not have the money to meet the judgment.

\section{Shifting directors duties from shareholders to creditors in the zone of insolvency}

The idea that prior to any formal filing for insolvency, the directors of a company may be obliged to consider the interests of the company's creditors to the exclusion of the company or its shareholders, can be traced back at least 20 years to the Australian case of Kinsela \& Anor v Russell Kinsela Pty Ltd (in liq). ${ }^{66}$ It was neatly summarised in the following terms by Street cj: ${ }^{67}$

In a solvent company the proprietary interests of the shareholders entitle them as a general body to be regarded as the company when questions of the duty of directors arise. If, as a general body, they authorise or ratify a particular action of the directors, there can be no challenge to the validity of what the directors have done. But where a company is insolvent the interests of the creditors intrude. They become prospectively entitled, through the mechanism of liquidation, to displace the power of the shareholders and directors to deal with the company's assets. It is in a practical sense their assets and not the shareholders' assets that, through the medium of the company, are under the management of the directors pending either liquidation, return to solvency, or the imposition of some alternative administration. 
This sentiment was approved shortly afterwards in the UK by Dillon lj in West Mercia Safetywear Ltd (in liquidation) v Dodd, ${ }^{68}$ and also appeared in American jurisprudence around the same time. ${ }^{69}$ A similar duty-shifting principle can be detected in New Zealand, although the leading case in this regard - Nicholson $v$ Permakraft (NZ) $L t d^{70}$ - reveals a degree of scepticism as to the appropriateness of this extension of the directors' duties. This scepticism, it should be added, is shared by highly authoritative commentators in South Africa, ${ }^{71}$ Australia, ${ }^{72}$ and the United States. ${ }^{73}$

The Canadian Supreme court in People's Department Stores Inc $v$ Wise, ${ }^{74}$ declared Canada possessed of this duty-shifting principle. This decision is more radical than the expressions of a similar principle in other jurisdictions, in the sense that it gives a clearly defined form to the duty which directors owe to creditors. It may have been limited to the duty of care in this case, but it was precisely that same duty of care as laid down in the Canadian Business Corporations Act. It might be true to say that all jurisdictions are vague in relation as to when the duty shifts, when, as it were, the debtor company crosses the line and enters the zone of insolvency. But, this aside, other formulations are much more tentative than that of the Canadian Supreme Court. Thus, in relation to the corresponding duty in the United States,

Although courts have uniformly held that directors of a corporation do not owe a fiduciary duty to bondholders, there is an important, but

68 West Mercia Safetywear v Dodd [1988] BCLC 250, which itself has been approved on a number of occasions, see eg Timothy Brown (as Liquidator of Cityspan Limited) v Nicholas Clark 2007 EWHC 751 (Ch); Facia Footwear v Hinchliffe [1998] 1 BCLC 218 at 228b-c; Re MDA Investment Management [2005] BCC 783, 805; Colin Gwyer \& Associates \& Anor v London Wharf (Limehouse) [2003] BCC 885, 906.

69 See Lin 1993 Vanderbilt Law Review 1512 (see authorities quoted in n 88 and 89); Coffee and Klein 1991 Univ of Chicago LR 1255-1256 (authorities in n 1401-142).

70 Nicholson $v$ Permakraft (NZ) [1985] 1 NZLR 242; on this and related decisions see the excellent comment on the first instance decision in Peoples Department Stores Inc v Wise, by Thomson 2000 UT Fac L Rev par 121-128.

71 See Havenga 1997 SA Mercantile LJ 318ff.

72 Worthington 1991-92 Melbourne University LR 121, 122, 133ff, $151 \mathrm{ff}$.

73 Hu and Westbrook 2007 Columbia Law Review 1321-1403.

74 People's Department Stores Inc $v$ Wise 244 DLR $\left(4^{\text {th }}\right) 564$, affirming the decision of the Quebec Court of Appeal, 224 DLR $\left(4^{\text {th }}\right) 509$, which in turn reversed in part the decision of Greenberg j [1998] QJ No 3571 (Quebec Superior Court). 
ill-defined, exception to this general rule, which arises when the corporation becomes insolvent. ${ }^{75}$

There is, however, an important yet ill-defined exception to the legal primacy of shareholder interests. Several courts have held that once the corporation becomes insolvent, directors owe a fiduciary duty to creditors. This shift of fiduciary obligation takes place even if insolvency occurs long before liquidation or commencement of bankruptcy proceedings. Arguably, this duty to creditors can be construed broadly to require directors to take actions that would maximize the creditors' interests once the firm becomes insolvent. On the other hand, this duty can be construed more narrowly to require only that the directors treat all creditors equally and to prohibit directors form withdrawing corporate assets for the benefit of themselves, shareholders, or some preferred creditors. ${ }^{76}$

Yet, diffident or not, made flesh as by the Canadian Supreme Court or left nebulous as in other jurisdictions, it is clear that the general consensus is that we are here talking about a duty owed to the creditors. ${ }^{77}$ Those who recall the firmness with which directors' duties were once stated to be owed to the company alone, or to the company and the shareholders alone, may swallow hard, but nevertheless accept this brave new world. Yet if we contrast this with what is accepted as being one of the first, if not the first, statement of this dutyshifting principle, we might wonder at the rapidity and extent of its development. Cheng Wai Yuen reminds us of what he aptly describes as Mr Justice Mason's "almost casual statement" which he regards as the "first explicit judicial recognition of any form of duty to corporate creditors". ${ }^{78}$

In [respect of the duty of directors to consider the best interests of creditors of the company] it should be emphasised that the directors of a company in discharging their duty to the company must take into account the interests of its shareholders and creditors. Any failure by the directors to take into account the interests of creditors will have adverse consequences for the company as well as for them. ${ }^{79}$ 
The duty described reads very much like part of the directors' duty to the company, and enforceable by the shareholders of the company (or where breached, ratifiable by the shareholders). What could be more sensible on the part of the directors in the execution of their responsibilities to the company, than to ensure that creditors, especially creditors on whom the company may well depend, are well treated. A failure to do so may be explained away by a short term liquidity and would be likely to attract understanding and ratification on the part of the shareholders. But a failure to do so that could not be readily explained and which caused loss to the company would certainly be open to redress by the shareholders. It may well be that Mr Justice Mason had no revolutionary intentions.

Now, however, that the genie is out of the bottle, should we regard this dutyshifting principle a desirable addition to the legal tools for the governance of insolvent companies? Its economic justification is to reset the balance between creditors and entrepreneurs, which, arguably is both presumptuous and cavalier. If something so fundamental is in need of adjustment, it can hardly be appropriate for this to come about in the form of a principle which is deeply uncertain both as to scope and incidence. 'Ill-defined' ${ }^{80}$ seems to be the closest we can get to describing it and the notion of a 'zone of insolvency' is quaint at best. An appropriate simile may be that of a blind man in a dark room looking for a black cat that isn't there. It is argued that in the United States the dutyshifting principle has a long tradition, deriving, from the old trust fund doctrine, ${ }^{81}$ whose origin is ascribed to a judgment of Justice Joseph Story in $1824,{ }^{82}$ but the link must be tenuous at best.

Yet, should not some thought be given to its widespread appearance? This is intriguing and may be a general response to some trend arising from recent global or near-global financial phenomena. But apart from a similar description in the several jurisdictions, it does not seem possible to construct out of these

80 See the text associated with $\mathrm{n} 46$ and 47.

81 In re Mortgage America Corporation 714 F 2d 1266, 1268-1269.

82 Wood v Dummer 30 F Cas 435 (D Me 1824) (No 17,994). 
various manifestations, a single legal principle. In particular - and apart from Canadian Peoples Department Stores Inc $v$ Wise ${ }^{83}$ - it is not possible to say whether the duty whose focus shifts from shareholders to creditors, is precisely the same duty or set of duties as that or those owed by the directors to the company and shareholders during the period when the company is a solvent, going concern. The director's fiduciary duty would seem a very uneasy transplant, given its emphasis on accountability for profits from unauthorised use of the company's property and its concern for the misappropriation of the company's property. If damages are awarded against a director for the misappropriation of the company's property, or the director is ordered to account for taking unauthorised profits or using a corporate opportunity for his or her own benefit, would the proceeds of such an award be impressed with a trust in favour of the creditors?

The director's duty of care seems a little more ripe for transplant, but if, indeed, the directors acted without due care and attention causing a diminution in the value of the company's property, would a single creditor really have a right of action against the directors during the period before any formal filing for insolvency? And, if so, would the claim be for the loss in value of the company's property or for the debt owed by the company to the creditor?

This may seem a somewhat satirical approach to this issue, but it does seem to me to highlight an important and as yet unexplored feature of this duty-shifting principle. One answer to the satirical questions may be that such circumstances are never contemplated and that these are duties whose breach only has consequences when the company is already in a formal insolvency and whose effect is only designed to swell the insolvent estate for the benefit of the whole class of creditors. But if this is so, in what sense is it appropriate to speak of the duty shifting before the formal insolvency is declared?

It is, to my mind, a telling fact that all the sources which declare the existence of the shift in the duty are concerned with events in the formal insolvency. Could 
we say with confidence that a creditor would have standing where, before any formal insolvency, he or she sought to prevent the directors from acting on a decision which the creditor believed would lessen the chances of his or her debt being paid? ${ }^{84}$

\section{Conclusion}

No one would dispute the principle that in a formal corporate insolvency, the estate should be charged with the payment, as far as possible, of the company's debts. One might also feel comfortable, if not entirely happy, with the principle that the estate should benefit from contributions by the directors and officers whose conduct contributed to the insolvent liquidation of the company. Equally, most people would accept the necessity that entrepreneurs should benefit from a principle which protects their own private estate should the company, through with the entrepreneurial activity being conducted, go into insolvent liquidation. Society, in general, it is thought, wants to encourage entrepreneurial activity and the limitation of the entrepreneur's liability is accepted as the necessary incentive for this. There is, clearly a delicate balance to be struck between creditors and entrepreneurs. If this is now thought to be in need of adjustment, in its current uncertain state, the shifting of the focus of the directors' duties does not seem appropriate for this purpose.

84 See the discussion of Lawrence $v$ West Somerset Mineral Railway Company (at 4, supra $\mathrm{n}$ 35). 


\section{Bibliography}

Alexander 1992 Harv L Rev 415

Alexander J "Unlimited Shareholder Liability Through a Procedural Lens" 1992 (106) Harv L Rev 387

Ballantine Corporations 303

Ballantine HW Corporations Rev ed (Callaghan New York 1946)

Berle 1947 Colum L Rev 349-353

Berle AA "The Theory of Enterprise Entity" 1947 (47) Colum L Rev 343

Campbell 1975 Ky LJ 53

Campbell RB "Limited Liability for Corporate Shareholders: Myth or MatterOf-Fact" 1975 (63) Kentucky Law Journal 23-27

Cheng Wai Yuen 2002 Sing LR 104

Cheng Wai Yuen M "Corporate Directors' Common Law Duty to Creditors? - A Revelation of the Present State of the Law" 2002 (22) Sing LR 104

Coffee and Klein 1991 Univ of Chicago LR 1207

Coffee JC and Klein WA "Bondholder Coercion: The Problem of Constrained Choice in Debt Tender Offers and Recapitalizations" 1991 (58) Univ of Chicago LR 1255-1256

Cohen 1998 Oklahoma Law Review 438

Cohen DL "Theories of the Corporation and the Limited Liability Company" 1998 (51) Oklahoma Law Review 427

Easterbrook and Fischel Economic Structure of Corporate Law Easterbrook F and Fischel DR The Economic Structure of Corporate Law (Harvard University Press Cambridge 1991) 
Formoy Historical Foundations of Company Law 32-36

Formoy RR The Historical Foundations of Company Law (Sweet \& Maxwell London 1923)

Davies and Gower Principles of Modern Company Law

Davies PL and Gower LCB Gower and Davies: Principles of Modern

Company Law $7^{\text {th }}$ ed (Sweet \& Maxwell London 2003)

Davies and Gower Gower's Principles

Davies PL and Gower LCB Gower's Principles of Modern Company Law $6^{\text {th }}$ ed (Sweet \& Maxwell London 1997)

Hamilton 1971 Texas LR 985-989

Hamilton RW "The Corporate Entity" 1971 (49) Texas LR 979

Havenga "Directors' Fiduciary Duties Under Our Future Company Law Regime" 1997 (9) SA Mercantile LJ 310, 318ff

Hu and Westbrook 2007 Columbia Law Review 1321-1403

Hu HTC and Westbrook JL "Abolition of the Corporate Duty to Creditors" 2007 (107) Columbia Law Review 1321-1403

Lin L "Shift of Fiduciary Duty upon Corporate Insolvency" 1993 (46) Vanderbilt Law Review 1485 at 1512

McCulloch Considerations on Partnerships with Limited Liability 10-11 McCulloch JR Considerations on Partnerships with Limited Liability (Longman, Brown, Green \& Longmans London 1856)

Pennington 1960 Mod LR 630

Pennington RR "The Genesis of the Floating Charge" 1960 Modern Law Review 630-646

Report of the Company Law Committee [Cmnd 1749] (1962)

$62 / 211$ 
Report of the Review Committee on Insolvency Law and Practice [Cmnd 8558] (1982)

Sigwadi 2003 SA Mercantile LJ 303

Sigwadi M "Personal Liability for the Debts of Close Corporations:

Compromise and Personal Liability under Section 424 of the Companies Act 61 of 1973" 2003 (15) SA Mercantile LJ 303

Thompson 1991 Cornell L Rev 1065

Thompson RB "Piercing the Corporate Veil: An Empirical Study" 1991 (76) Cornell L Rev 1036

Thomson D "Directors, Creditors and Insolvency: A Fiduciary Duty or a Duty Not to Oppress?" 2000 (58) UT Fac L Rev 31

Vandervoort 2004 DePaul Bus \& Comm LJ 53-56

Vandervoort JK "Piercing the Veil of Limited Liability Companies: The Need for a Better Standard" 2004 (3) DePaul Bus \& Comm LJ 51

Worthington S "Directors' Duties, Creditors' Rights and Shareholder Intervention" 1991-92 (18) Melbourne University LR 121, 122, 133ff, $151 \mathrm{ff}$

Ziegel 1993 UTLJ 511

Ziegel JS "Creditors as Corporate Stakeholders: The Quiet Revolution - An Anglo-Canadian Perspective" 1993 (43) University of Toronto Law Journal 511

\section{Register of legislation}

Business Corporations Act (Ca)

Close Corporations Act 69 of 1984 (SA)

Companies Act 1862 (UK)

Companies Act 1929 (UK)

Companies Act 2006 (UK) 
Companies Act 61 of 1973 (SA)

Corporations Act 2001 (Aust)

Enterprise Act 2002 (UK)

Insolvency Act 1986 (UK)

Joint Stock Companies Act 1844

Limited Liability Act 1855

Limited Partnership Act 1907

Partnership (Amendment) Act 1854 (Bovill's Act)

Partnership Act 1890

\section{Register of court cases}

Broderip v Salomon [1895] 2 Ch 323

Colin Gwyer \& Associates Ltd \& Anor v London Wharf (Limehouse) Ltd \& Ors [2003] BCC 885

Edwards v Standard Rolling Stock Syndicate [1893] 1 Ch 574

Facia Footwear Ltd (in admin) v Hinchliffe [1998] 1 BCLC 218

Grace v Smith (1775) 96 ER 587, 588; 2 Wm BI 997

Hallett $v$ Dowdall (1852) 21 LJ QB 98

Harri and Others NNO v On-Line Management CC \& Others 2001 (4) SA 1097 In re Mortgage America Corporation 714 F 2d 1266

In Re Victoria Steamboats, Limited [1897] 1 Ch 158

Inland Revenue Commissioners v Goldberg [1972] Ch 498

JH Rayner Mincing Lane Ltd and Others $v$ Department of Trade and Industry and Others [1987] BCC 413

Kinsela \& Anor v Russell Kinsela Pty Ltd (in liquidation) [1986] 4 NSWLR 722; (1986) 4 ACLC 215

L \& P Plant Hire BK en andere v Bosch en andere 2002 (2) SA 662

Lawrence $v$ West Somerset Mineral Railway Company [1918] 2 Ch 250

Lordon NO v Dusky Dawn Investments (Pty) Ltd (in liquidation) 1998 (4) SA 519

Makins v Percy Ibotson \& Sons [1891] 1 Ch 133

Nicholson v Permakraft (NZ) Ltd [1985] 1 NZLR 242

Peek v Trinsmaran Iron Company 2 Ch D 115 
People's Department Stores Inc v Wise 244 DLR $\left(4^{\text {th }}\right) 564$

Pressma Services (Pty) Ltd v Schuttler and another 1990 (2) SA 411

Queensland Bacon Pty Ltd v Rees (1966) 115 CLR 266

Re Darby [1911] 1 KB 95

Re MDA Investment Management Ltd [2005] BCC 783

Re New York Taxicab Company Limited [1913] 1 Ch 1

Re Panama, New Zealand and Australian Royal Mail Company (1870) 5 Ch app 818

Re Sea Fire and Life Assurance Company (Greenwood's case) (1854) 3 De

GM\&G 459, 43 ER 180

Re Tilt Cove Copper Company Limited [1913] 2 Ch 58

Salomon v Salomon \& Co Ltd [1897] AC 22

Timothy Brown (as Liquidator of Cityspan Limited) v Nicholas Clark 2007

EWHC 751 (Ch)

Victoria Steamboat [1897] 1 Ch 158

Walker v Wimborne [1975] 137 CLR 1

Waugh v Carver (1793) 126 ER 525, 2 Hy BI 235

West Mercia Safetywear Ltd (in liquidation) v Dodd [1988] BCLC 250

Westminster Corporation v Haste [1950] Ch 442

Wood v Dummer 30 F Cas 435 (D Me 1824) (No 17,994)

\section{Register of Internet resources}

Bentham Manual of Political Economy http://socserv.mcmaster.ca/ 27 Feb

Bentham J Manual of Political Economy [Found on internet]

http://socserv.mcmaster.ca/econ/ugcm/3/l3/bentham/manualpoliticalecono

my.pdf [Date of use 27 February 2008]

\section{List of abbreviations}

$\begin{array}{ll}\text { app } & \text { appendices } \\ \text { ch } & \text { chapter(s) } \\ \text { par } & \text { paragraph(s) } \\ \text { reg } & \text { regulation(s) } \\ \text { s } & \text { section(s) }\end{array}$


sch

schedule(s)

$66 / 211$ 